\title{
SOSIALISASI DAN PELATIHAN TEKNOLOGI TEPAT GUNA PEMBUATAN EKSTRAK KULIT KACANG METE UNTUK ANTIVIRAL NABATI PADA TANAMAN KEDELAI
}

\author{
Wuye Ria Andayanie ${ }^{1}$, Netty Ermawati ${ }^{2}$ \\ ${ }^{1}$ Program Studi Agroteknologi, Fakultas Pertanian \\ Universitas Merdeka Madiun \\ ${ }^{2}$ Program Studi Teknik Produksi Benih D4, Politeknik Negeri Jember \\ Email: wuye.andayanie@gmail.com
}

\begin{abstract}
Cashewplants is one of the plantation commodities in Indonesia that has higheconomic value. Cashew nut shell waste can be used as a botanical antiviralfor Cowpea mild mottle virus. This activity aims for soybean farmers to be able to provide their own insecticidal at low prices and easily ob tained. The method used viz. : 1) an interview andobservation, 2) the method of socialization with lectures and discussions or questions and answers; 3) training methods with lecture, demonstrations and direct practice with demoplot. Based on the analysis of community service programs, the following conclusions are obtained: 1) in terms of achievements based on the objectives, substance and efforts of this community service program, it is considered to be veryeffective in building community independence based on local potential, namely waste originating from cashew nut shells and soybean planting in forest shade area; 2) in terms of the results, benefits and impacts resulting from this community service program are numerous, namely: increasing public awareness to utilize waste originating from cashew nut shell wastefor antiviral, increasing community knowledge and skills in the field of processing waste cashew nut shell for botanical antiviral.
\end{abstract}

Keywords: soybean, cashew nut shell, socialization, training, group offarmers

\begin{abstract}
Abstrak. Ta naman jambu mete merupakan salah satu komoditas perkebunan di Indonesia yang memilik i nilai ekonomitinggi. Limbah kulit kacang mete dapat digunakan sebagai antiviral nabati untuk Cowpea mild mottle virus. Kegia tan ini bertujuan agar petani kedelai dapat menyediakan antiviral sendiri den gan harga murah dan mudah didapat. Metode yang digunakan: 1) wawa ncara dan observasi, 2) m et ode sosia lisa si dengan ceramah dan diskusi a tau tanya jawab; 3) metode pelatihan dengan ceramah dan dem onstrasi serta praktek langsung dengan demoplot. Berdasarkan a nalisis program pengabdian ke pa da masyarakat, diperoleh kesimpulan sebagai berikut: 1) dari segi ca paian sesuai tujuan, substansi dan upaya program pengabdian masyarakat ini dinilai sa ngat efektif dalam membangun kemand irian mas ya rakat berbasis potensi lokal, yaitu limbah yang berasaldarikulit $\mathrm{k}$ a cang me te $\mathrm{d}$ an penanaman kedelai di kawasan hutan lindung; 2) Dari segi ha sil, manfaat dan dampak yang dihasilkan dari program pengabdian kepada masyarakat ini sa ngat banyak, yaitu: meningkatkan kesadaran masyarakat untuk me manfa atkan limbah yang berasal dari limbah ku lit kacang mete sebagai antiviral, menin gkatkan pen getahuan d an keterampilan masyarakat dibidang pengolahan limbah kacang mete untuk antiviral nabati.

Kata kunci : kedelai, kulit kacang mete, sosialisasi, pelatihan, kelompok tani
\end{abstract}

\section{PENDAHULUAN}

Kulit kacang mete merupakan limbah dari pengolahan kacang mete dan belum dimanfaatkan secara optimal. Selain itu ekspor dalam bentuk gelondong menyebabkan potensi produksi dari kulit kacang mete hilang dimanfaatkan negara lain, sehingga pada posisi seperti ini Indonesia rugi karena hilangnya nilai tambah dari kulit kacang mete. Kondisi ini menuntut pemilihan teknologi yang tepat dan efisien dalam penanganan limbah kulit kacang mete, sehingga potensi ketersediaan bahan baku yang ada dapat dimanfaatkan secara optimal.

Saat ini, para petani jambu mete hanya mengambil biji metenya saja, sedangkan daging buah dan kulit kacang mete terbuang. Potensi sumber daya alam, khususnya kulit kacang mete di Desa Jenggrik kecamatan Kedunggalar mampu menghasilkan 118 kuintal setiap panen dan limbah kulit kacang mete belum secara maksimal digarap oleh petani jambu mete. Kesejahteraan petani dan pedagang mete masih rendah karena 
produktivitas mete berfluktuasi, miskin nilai tambah, juga rendahnya tingkat harga saat panen ray . Kulit kacang mete mempunyai peluang untuk dikembangkan menjadi produk-produk derivat lainnya, seperti insektisida dan antiviral. Potensi minyak nabati dari kulit kacang mete untuk pestisida sangat cerah, jika ditambahkan sabun cair sebagai pengemulsi mempunyai daya racun lebih tinggi untuk mengimbas Cowpea mild mottle virus (Andayanie et al., 2019).

Permasalahan yang dihadapi mitra adalah petani sering mengandalkan pestisida kimia untuk mengendalikan kutu kebul (Bemisia tabaci) yang merupakan vektor Cowpea mild mottle virus pada tanaman kedelai. Pestisida kimia mempunyai dampak negatif dari residu pestisida. Residu pestisida dapat menimbulkan pencemaran lingkungan, terbunuhnya musuhmusuh alami, terjadinya resistensi, resurgensi hama, dan berbahaya bagi manusia lingkungan serta manusia ( Singkoh \& Katili, 2019). Selain itu jambu mete produksi limbah kacang mete berlimpah saat panen raya, sehingga masyarakat tidak berdaya dalam memecahkan masalah kulit kacang mete di lingkungannya.. Limbah kulit kacang mete dapat dimanfaatkan sebagai bahan antiviral untuk CPMMV dengan pengetahuan dan ketrampilan masyarakat. Salah satu prinsip sosialisasi dan pelatihan untuk pemberdayaan masyarakat adalah pengakuan akan pengalaman dan pengetahuan lokal masyarakat. Hal ini menunjukkan bahwa masyarakat selamanya benar dan harus dibiarkan tidak berubah. Kenyataan ini membuktikan bahwa perkembangan pengalaman dan pengetahuan lokal (bahkan tradisional) masyarakat tidak sempat mengejar perubahan-perubahan yang terjadi dan tidak lagi dapat memecahkan masalah-masalah yang berkembang.

Mengingat adanya keterbatasan teknologi pada kelompok masyarakat penanam pohon mete dan petani kedelai mengakibatkan rendahnya produktivitas dan efisiensi pemanfaatan limbah kulit kacang mete. Sosialisasi dan pelatihan Teknologi Tepat Guna limbah kulit kacang mete dilakukan dengan pendekatan dan observasi hasil pelatihan serta perkembangannya pada masyarakat penanam jambu mete dan petani kedelai. Tujuan dari kegiatan sosialisasi dan pelatihan ini antara lain:1. bertambahnya pengetahuan dan ketrampilan masyarakat penanaman pohon jambu mete untuk penanganan limbah kulit kacang mete; 2. meningkatkan pengetahuan petani kedelai dampak penggunaan pestisida kimia secara terus menerus atau tidak bijaksana bagi lingkungan, misalnya matinya musuh-alami dari hama; 3 . petani kedelai dapat menyediakan antiviral sendiri dengan teknologi yang sederhan, murah dan mudah diperoleh;4. petani kedelai dan masyarakat penanam pohon jambu mete dapat membuat insektisida atau antiviral nabati dari limbah kulit kacang mete dengan kemasan serta masa simpan yang lama serta dapat menjualnya untuk menambah pendapatan dari masyarakat tersebut. Target dan luaran kegiatan ini mengukur tingkat keberhasilan sosialisasi dan pelatihan dengan evaluasi pada proses kegiatan dan produk dari antiviral yang dihasilkan.

\section{METODE PELAKSANAAN}

Kegiatan pengabdian pada masyarakat dilaksanakan pada bulan Oktober sampai Desember 2019. Tahap awal yang dilakukan dalam pengabdian masyarakat ini adalah observasi lingkungan di Desa Jenggrik, Kecamatan Kedunggalar-Kabupaten Ngawi. Observasi ini dilakukan selama satu bulan yakni bulan Oktober 2019. Dalam observasi ini melibatkan kelompok masyarakat penanam pohon jambu mete dan petani kedelai di lingkungan Desa Jenggrik.

Metode yang digunakan : 1) wawancara dan observasi, 2) metode sosialisasi dengan ceramah dan diskusi atau tanya jawab; 3) metode pelatihan dengan ceramah dan demonstrasi serta praktek langsung dengan demoplot. Peserta sosialisasi dan pelatihan di Desa Jenggrik sebanyak 23 orang petani kedelai dan 8 orang masyarakat penanam pohon mete. Pembuatan antiviral dari kulit kacang mete dengan teknik penggilingan dan pemisahan tertera pada Gambar 1. 


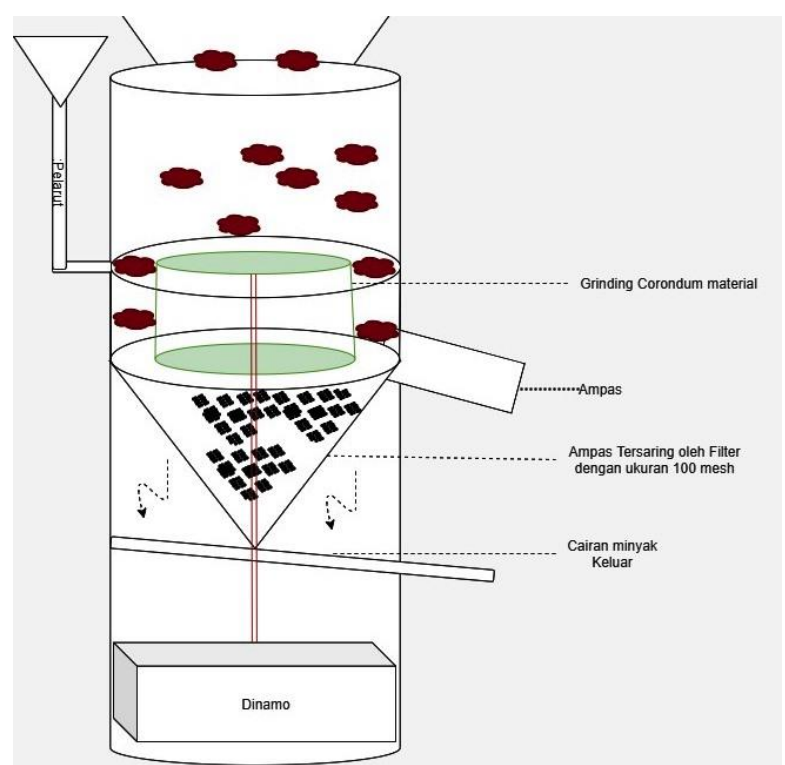

Gambar 1. Mesin penggiling dan pemisah untuk kulit biji jambu mete

Keterangan: Mesin penggiling dan pemisah ini terdiri atas bagian: 1. Grinding Batu berjenis corundum stone; 2. Filter terbuat dari stainless steel; 3. UP pole penghubung grinding ke mesin; 4. Bottom pole penghubung mesin ke grinding

Teknologi dan proses produksi dilakukan dengan cara sebagai berikut:

1. Bahan berupa kulit biji jambu mete, air, emulsifier

2. Kulit biji jambu mete $(2 \mathrm{~kg})$ dibersihkan dari kotoran di air mengalir dan dikeringanginkan hingga berat bahan berkurang $30 \%$.

3. Kulit biji jambu mete kadar air di masukkan di cone penampungan dan dilanjutkan dengan proses penggilingan. Selama proses penggilingan dimasukkan campuran air dan emulsifier (20 cc/l air) sedikit demi sedikit.

4. Hasil proses penggilingan berupa air, emulsifier, ampas dan minyak.

5. Tahapan pemisahan atau separation dilakukan untuk memisahkan ampas dengan air, emulsifier dan minyak.

6. Hasil pemisahan berupa konsentrat ekstrak kulit kacang mete dan ampas.

Pembuatan antiviral juga dilakukan dengan teknik penyangraian (roasting). Proses produksi minyak kulit kacang mete ini sangat sederhana dilakukan oleh ibu-ibu dari kelompok tani seperti tertera pada Gambar 2.

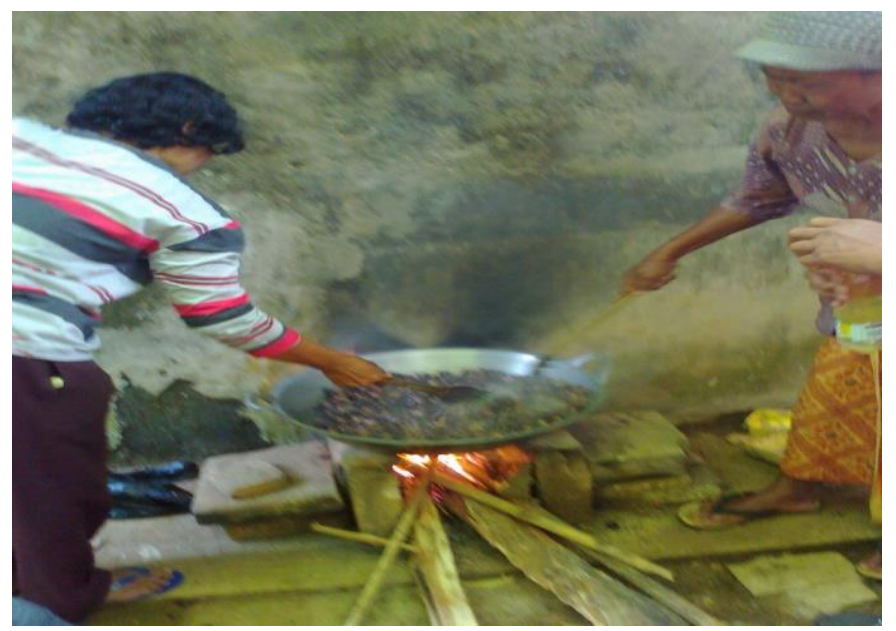

Gambar 2. Cara mengeluarkan minyak kulit kacang mete dengan penyangraian (roasting) oleh ibu-ibu kelompok tani 
Proses penyangraian dilakukan dengan cara sebagai berikut:

1. Bahan berupa kulit kacang mete, dan minyak kelapa

2. Kulit kacang mete $(2 \mathrm{~kg})$ dibersihkan dari kotoran di air mengalir dan dikeringanginkan hingga berat bahan berkurang $30 \%$.

3. Kulit kacang mete kadar air di masukkan di tempat penyangraian setelah kulit panas diberi minyak kelapa untuk merangsang minyak di dalam kulit kacang mete.

4. Setelah mengeluarkan minyak bahanyang disangrai didinginkan dan disaring sebagai cairan pekat

kulit kacang mete. Namun untuk aplikasinya di lapang 5 cc minyak perlu ditambahkan emulsifier (sabun cair) $2 \mathrm{cc} /$ liter air, sehingga minyak kulit kacang mete dapat homogen di dalam pelarut untuk siap disemprotkan

\section{HASIL DAN PEMBAHASAN}

Hasil kegiatan terapan pengabdian masyarakat yang dilaksanakan di Desa Jenggrik,
Kecamatan Kedunggalar, Kabupaten Ngawi sebagai berikut:

\section{A. Survei}

Berdasarkan data hasil survei di Desa Jenggrik, Kecamatan Kedunggalar Kabupaten Ngawi menunjukkan bahwa Desa Jenggrik memiliki kelompok tani kedelai yang ditanam di areal kawasan hutan dan sebagian masyarakatnya mempunyai pohon jambu mete. Oleh karena itu penerapan teknologi penggunaan antiviral nabati dari kulit biji jambu mete untuk CPMMV pada tanaman kedelai sangat dibutuhkan masyarakat di wilayah tersebut. Potensi limbah yang berasal dari kulit biji jambu mete hanya dianggap limbah yang mencemari lingkungan dan belum termanfaatkan secara optimal. Hasil observasi awal juga diperoleh bahwa masyarakat belum memiliki pengetahuan dan keterampilan yang cukup pada usaha pengolahan kulit kacang mete sebagai antiviral nabati untuk CPMMV pada tanaman kedelai. Hasil survei tentang potensi masyarakat di Desa Jenggrik dapat dilihat pada Tabel 1.

Tabel 1. Hasil survei kondisi masyarakat

\begin{tabular}{ll}
\hline \multicolumn{1}{c}{ Aktivitas survei } & Hasil \\
\hline Jumlah kepala keluarga (KK) & $51 \mathrm{KK}$ \\
\hline Rata-rata jumlah anggota KK & 4 orang \\
\hline Rata-rata jumlah pohon mete & 11 pohon \\
\hline Rata-rata jumlah kulit biji jambu mete/panen & 7,2 kuintal \\
\hline Tingkat pendidikan masyarakat & SD \\
\hline Rata-rata kondisi ekonomi masyarakat & Menengah kebawah \\
\hline $\begin{array}{l}\text { Tanggapan masyarakat tentang teknologi pembuatan } \\
\text { antiviral nabati dari kulit kacang mete }\end{array}$ & Tertarik \\
\hline Rata-rata pekerjaan masyarakat & Petani dan buruh tani \\
\hline
\end{tabular}

Sebagian besar masyarakat menanggapi positif dan tertarik tentang pemanfaatan kulit kacang mete sebagai alternatif penggunaan insektisida kimia. Kelompok tani kedelai yang tergabung dalam kelompok petani "Suka Makmur", setiap anggota mempunyai lahan ratarata seluas $275 \mathrm{~m}^{2}$. Lahan ini ditanami kedelai setelah jagung atau jagung dengan tumpangsari kedelai. Anggota kelompok tani ini berjumlah 23 orang. Selain itu penanaman pohon jambu mete juga dilakukan oleh masyarakat dengan jumlah pohon jambu mete sebanyak 11 pohon dengan limbah kulit biji jambu 7,2 kuintal setiap panen. Ini merupakan asset yang berharga bagi Desa Jenggrik, apabila kulit kacang mete dapat dimanfaatkan dan dikelola dengan baik serta benar.

\section{A. Sosialisasi}

Sosialisasi yang dilakukan dalam penerapan pengabdian masyarakat ini bertujuan untuk memberi pengetahuan kepada warga masyarakat tentang pengelolaan limbah kulit kacang mete menjadi antiviral nabati untuk 
CPMMV pada tanaman kedelai. Sasaran program ini adalah masyarakat yang memiliki pohon jambu mete dan kelompok petani kedelai "Suka makmur" Desa Jenggrik. Sosialisasi ini dilakukan dalam rangka:

1. Memberikan pengetahuan kepada masyarakat tentang potensi pemanfaatan limbah kulit kacang mete, sehingga bernilai ekonomi tinggi.

2. Memperkenalkan teknologi pembuatan antiviral nabati yang berasal dari kulit kacang mete sebagai pengganti insektisida kimia untuk mengendalikan CPMMV pada tanaman kedelai, sehingga bernilai ekonomi tinggi.

Sosialisasi dilaksanakan pada hari/tanggal

: Kamis/ 03 dan 27 Oktober 2019, pukul 19.00-
21.00 bertempat di rumah bapak Ngadikun (Ketua Kelompok tani kedelai “Suka Makmur”). Kegiatan ini diikuti oleh 17 peserta. Materi sosialisasi yang diberikan adalah potensi limbah yang berasal dari kulit biji jambu mete. Pada saat sosialisasi antusias masyarakat sangat baik. Hal ini ditunjukkan dengan pertanyaan yang diajukan karena telah lama kulit kacang mete menyebabkan pencemaran lingkungan (menimbulkan bau tidak sedap dan rendahnya tingkat kebersihan di lingkungan masyarakat pengacip biji mete saat panen raya) dan pemahaman tentang pestisida nabati dari kulit kacang mete serta soft skill untuk memproduksinya sangat terbatas (Tabel 2).

Tabel 2. Perbandingan sebelum dan sesudah kegiatan sosialisasi pemanfaatan limbah kulit kacang mete

\begin{tabular}{lllll}
\hline No & Indikator kegiatan & Sebelum & Sesudah & \multicolumn{1}{c}{ Keterangan } \\
\hline 1 & $\begin{array}{l}\text { Pemahaman tentang } \\
\text { pestisida nabati dari kulit } \\
\text { biji jambumete }\end{array}$ & Terbatas & Meningkat & Peserta aktif \\
\hline 2 & $\begin{array}{l}\text { Soft skill produksiantiviral } \\
\text { darikulit kacang mete }\end{array}$ & Tidak bisa & Terampil & Peserta aktif \\
\hline 3 & $\begin{array}{l}\text { Produk antiviralnabati } \\
\text { dengan teknologi } \\
\text { penggilingan dan } \\
\text { pemisahan }\end{array}$ & Tidak ada & Ada & $\begin{array}{l}\text { Perlu penambahan emulsifier (m isaln ya } \\
\text { sabuncair 20 cc/lair) }\end{array}$ \\
\hline 4 & $\begin{array}{l}\text { Produk antiviralnabati } \\
\text { dengan teknologi } \\
\text { penyangraian (roasting) }\end{array}$ & Tidak ada & Ada & $\begin{array}{l}\text { Perlu penambahan emulsifier (m isaln ya } \\
\text { sabuncair/20 cc/lair) }\end{array}$ \\
\hline
\end{tabular}

Kegiatan ini telah berhasil mensinergikan seluruh kegiatan ke petani mitra dan warga penanam pohon jambu mete untuk merespon penanganan limbah kacang mete sebagai antiviral CPMMVpada tanaman kedelai. Sosialisasi juga dilaksanakan untuk kelompok istri petani kedelai. Hal ini karena sebagian besar istri petani kedelai tidak bekerja hanya sebagai ibu rumah tangga. Program sosialisasi pemanfaatan limbah yang berasal dari kulit kacang mete diharapkan tumbuh kesadaran untuk memanfaatkan limbah kulit kacang mete menjadi sesuatu yang bernilai ekonomi tinggi. Kegiatan ini diikuti oleh 16 peserta. Materi yang disampaikan antara lain: (1) pengolahan limbah yang berasal dari kulit kacang mete menjadi minyak dengan teknik roasting; (2) pengolahan limbah yang berasal dari kulit kacang mete menjadi minyak dengan teknik penggilingan dan pemisahan; (3) menumbuhkan usaha baru mandiri untuk meningkatkan kesejahteraan keluarga; (4) manajemen pengolahan dan pemasaran produk. Antusias masyarakat penanam pohon jambu mete dan kelompok tani kedelai serta istri sangat besar seperti yang ditunjukkan pada Gambar 3 . 


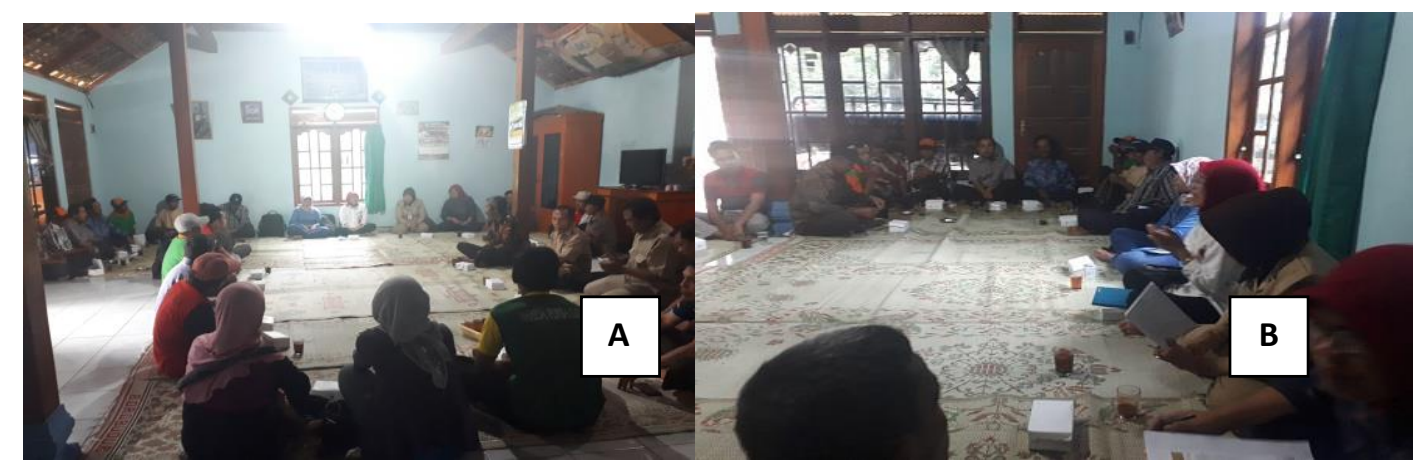

Gambar 3. A. Kegiatan sosialisasi pada warga penanam pohon jambu mete dan petani kedelai "Suka Makmur" serta istri; B. Kegiatan sosialisasi juga dihadiri oleh penyuluh pertanian, dari Kecamatan Kedunggalar

Mitra berharap pemanfaatan limbah berasal dari kacang mete menjadi antiviral bisa mengatasi virus CPMMV pada tanaman kedelai dan membuka lapangan pekerjaan untuk ibu rumah tangga di desa tersebut dengan memproduksi insektisida untuk kutu kebul dan antivirus untuk CPMMV.

\section{Pelatihan}

Pelatihan pembuatan antiviral nabati dari kulit kacang mete dimaksudkan untuk dapat memperbaiki dan mengembangkan sikap, tingkah laku, ketrampilan dan pengetahuan dari peserta sesuai dengan yang diinginkan instruktur.

Perubahan masyarakat di Desa Jenggrik setelah mengikuti pelatihan pemanfaatan kulit kacang mete untuk antiviral nabati antara lain:

1. Meningkatnya kesadaran masyarakat khususnya warga penanam pohon jambu mete dan pengacip kacang mete dan kelompok tani kedelai tentang:

a) limbah kulit kacang mete dapat diolah menjadi bahan yang bernilai ekonomi agar tidak mencemari lingkungan;

b) kulit kacang mete dapat diolah menjadi antiviral nabati berguna untuk tanaman kedelai dari serangan virus CPMMV.
2. Tumbuhnya minat masyarakat untuk produksi insektisida dan antiviral nabati dari kulit kacang mete.

3. Meningkatnya ketrampilan masyarakat untuk membuat antiviral nabati yang berkualitas dari kulit kacang mete.

4. Terbentuknya kelompok usaha pengolahan kulit kacang mete menjadi antiviral nabati bernilai ekonomi, sehingga menambah penghasilan masyarakat setempat.

5. Lingkungan warga penanam pohon mete dan pengacip biji mete menjadi lebih bersih, karena limbah kulit kacang mete yang awalnya mencemari lingkungan, menyebabkan bau sekarang termanfaatkan untuk usaha baru yaitu pembuatan antiviral nabati.

Kegiatan pelatihan ini dilaksanakan pada hari Selasa 06 \& 20 Desember 2019 pukul 0.9.00-10.00, bertempat di rumah bapak Ngadikun. Kegiatan ini diikuti oleh 18 peserta. Setiap peserta diberi kesempatan untuk praktek langsung pembuatan antiviral nabati dari kulit kacang mete dan memformulasikan untuk aplikasi di lahan demplot (Gambar 4).

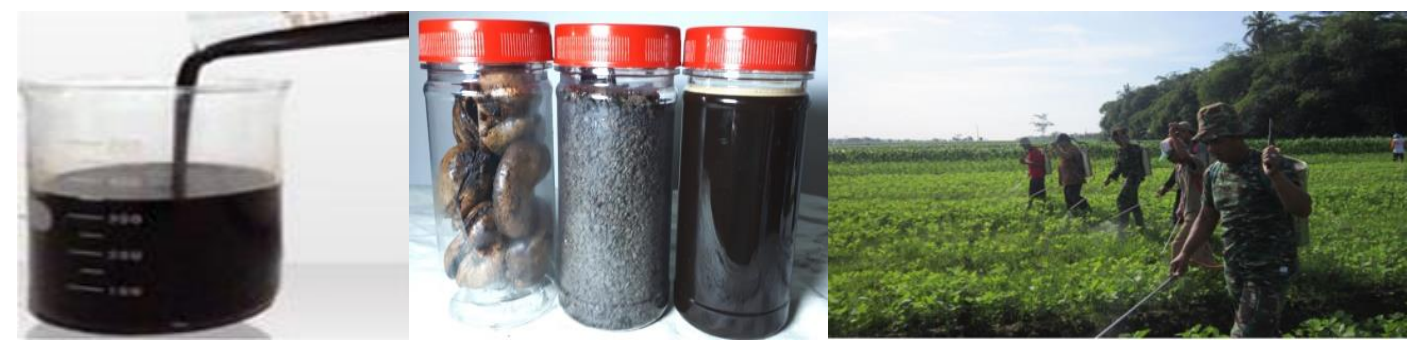

Gambar 4. A. Cairan hitam dari kulit kacang mete yang dihasilkan dari proses penggilingan dan pemisahan; B. Minyak berwarna hitam dari proses penyangraian kulit kacang mete ; C. aplikasi di lahan demplot oleh kelompok tani "Suka makmur". 
Langkah-langkah dilakukan untuk membuat antiviral sebagai berikut:

1. Antiviral nabati ini dapat dibuat dengan proses penggilingan dan pemisahan.

2. Antiviral nabati ini dapat dibuat dengan penyangraian (roasting).

Persentase dari senyawa yang dihasilkan dari kulit kacang mete tergantung dari proses pembuatannya, yaitu proses panas atau dingin. Proses dingin dengan penggilingan dan pemisahan akan menghasilkan asam anakardat yang cukup tinggi. Sedangkan proses panas dengan penyangraian dilakukan dengan memanggang kulit biji hingga keluar minyaknya. Minyak kulit biji mete yang dibuat dengan proses pemanasan akan menghasilkan senyawa kardanol yang cukup tinggi. Hal ini terjadi karena proses karboksilasi asam anakardat menjadi kardanol.Proses penggilingan dan pemisahan menghasilkan cairan berwarna hitam, sedangkan dengan proses penyangraian kulit kacang mete menghasilkan minyak kulit kacang mete berwarna hitam.

Proses penyangraian perlu ditambahkan minyak kelapa untuk merangsang keluarnya minyak mete. Minyak mete tersebut disaring untuk dipisahkan dari kulit. Proses ini dapat dilakukan tanpa ketrampilan tinggi, sehingga semua orang bisa melakukan dengan mudah. Namun demikian penyangraian mempunyai kelemahan-kelemahan dan keterbatasan karena tidak menghasilkan asam anakardat.

\section{SIMPULAN}

Berdasarkan hasil analisa program pengabdian masyarakat telah dilakukan teknologi tepat guna pemanfaatan limbah kulit biji jambu mete sebagai antiviral nabati untuk CPMMV pada tanaman kedelai di Desa Jenggrik Kecamatan Wonokerto Kabupaten Ngawi dapat disimpulkan sebagai berikut:

a. Ditinjau dari aspek capaian berdasarkan tujuan, substansi dan usaha program pengabdian masyarakat ini dipandang sangat efektif untuk membangun kemandirian masyarakat yang berbasis potensi lokal yakni limbah yang berasal dari kulit kacang mete dan penanaman kedelai di kawasan naungan hutan. b. Ditinjau dari aspek hasil, manfaat dan dampak yang dihasilkan dari program pengabdian masyarakat ini sangat banyak yaitu: meningkatkan kesadaran masyarakat untuk memanfaatkan limbah yang berasal dari limbah kulit kacang mete untuk antiviral nabati, meningkatkan pengetahuan dan ketrampilan masyarakat bidang pengolahan limbah yang berasal dari kulit kacang mete untuk antiviral nabati, tumbuhnya kelompok usaha pengolahan limbah kulit kacang mete untuk antiviral nabati di Desa Jenggrik, Kecamatan Kedunggalar Kabupaten Ngawi.

\section{SARAN}

Warga Desa Jenggrik perlu memperoleh pendampingan karena telah berhasil membuat antiviral nabati dari limbah kulit kacang mete yang ramah lingkungan untuk CPMMV pada tanaman kedelai dan digunakan sebagai alternatif pengganti pestisida kimia. Selain itu dapat digunakan untuk menambah penghasilan warga yang menanam jambu mete untuk mengolah limbah kulit kacang mete sebagai antiviral untuk CPMMV pada tanaman kedelai.. Agar pengelolaan dalam pembuatan dan pemasaran antiviral nabati untuk CPMMV tersebut berlangsung lancar, maka perlu dibentuk kelompok usaha pemasaran antiviral nabati dari kulit kacang mete.

\section{UCAPAN TERIMAKASIH}

Ucapan terima kasih disampaikan kepada warga penanam pohon jambu mete dan kelompok tani kedelai “ Suka Makmur” Desa Jenggrik, Kecamatan Kedunggalar, Kabupaten Ngawi sebagai mitra dalam pelaksanaan Sosialisasi dan Pelatihan Teknologi Tepat Guna Pembuatan Ekstrak Kulit Kacang Mete untuk Antiviral Nabati pada Tanaman Kedelai.

\section{DAFTAR PUSTAKA}

Andayanie, W.R., Nuriana, W., \& Ermawati, N. (2019). Bioactive compounds and their their antifeedant activity of cashew nut (Anacardiaceae) shell extract against Bemisia tabaci (Hemiptera:Aleyrodidae). Acta Agriculturae Slovenica.113 (2): 8390. 
Andayanie, W.R., Nuriana, W., \& Ermawati, N. (2019). Antiviral activity of cashew nut shell extract against Cowpea mild mottle virus on soybean. J. Hama dan Penyakit Tumbuhan Tropika. 19 (2): 170-178.

BPS KABUPATEN NGAWI. (2018). Kecamatan Kedunggalar Dalam Angka 2019.

Singkoh, M. \& Katili D.Y. (2019). Bahaya pestisida sintetik (sosialisasi dan pelatihan bagi wanita kaum ibu desa Koka Kecamatan Tombulu Kabupaten Minahasa). J. Perempuan dan Anak Indonesia. 1(1): 5-1. 